J. Perinat. Med.

13 (1985) 201

\title{
Intrauterine fetal activity in at term and prolonged pregnancies
}

\author{
E. Z. Zimmer, M. Y. Divon, I. Goldstein, Z. Sarna*, E. Paldi
}

Departments of Obstetrics and Gynecology " $\mathrm{B}$ " and * Medical Bioengineering, Rambam Medical Center, Technicon - Faculty of Medicine, Haifa, Israel

\section{Introduction}

Prolonged pregnancy has been reported to be at higher risk of antepartum and intrapartum fetal distress as well as developmental disorders of the newborn $[1,2,7]$. Early prediction of the fetus at risk is of great value. Unfortunately there are conflicting results regarding the predictive value of the methods in use at present $[7,8]$. The aim of our study was to determine if fetal breathing and body movements before and after maternal glucose administration have a predictive value of the fetus risk in prolonged pregnancy.

\section{Material and methods}

Informed consent was obtained from 26 healthy women with normal fetuses. In all of them an accurate gestational age was confirmed using strict criteria [7]. Six women were at 280 days of gestation and all of them underwent an elective cesarean section (Group A). In twenty women who were at 294 days of gestation, induction of labor was performed. Based on the infant's external characteristics and the ClifFoRD's classification [1] 12 of these fetuses were classified as post-term (Group B) and 8 were classified as stage I post mature (Group C).

Fetal breathing and body movements were recorded with a real time ultrasound scanner

\section{Curriculum vitae}

ETAN Z. Zimmer, M. D., was born in Israel in 1945. Graduated from the Hadassah Medical School in Jerusalem in 1972. He specialized in Obstetrics and Gynecology and is now a senior physician in the Department of Ob/Gyn at the Rambam Medical Center, Haifa, Israel. Major interests are high risk obstetrics, fetal monitoring and ultrasonography.

24-48 hours prior to delivery. All studies were performed at least 3 hours after meal in a quiet room while patients were resting in the left semirecumbent position. Changes in two physiological events were studied by the observer. One was an alteration in breathing movements while the other was an alteration during each fetal trunk movement. The information was recorded on an F. M. tape and analyzed by a Compucolor II computer. Apnea was defined as the absence of breathing movements for six or more seconds. There were two recording periods of $25 \mathrm{~min}$ each, before and half an hour after maternal IV administration of $50 \mathrm{gr}$ glucose. The injection contained $500 \mathrm{cc}$ of $10 \%$ glucose solution and was given over 10 minutes. The incidence (duration in seconds) of breathing movements and body movements was statistically analyzed using the WILCOXON matched pairs signed ranks test and the Wilcoxon rank sum test. 


\section{Results}

\section{Fetal body movements}

The incidence of body movements did not change significantly in any group of fetuses after maternal glucose administration. There was no significant difference in the incidence of body movements among the three groups of fetuses.

Fetal breathing movements (Tab. I)

A significant rise was noted in the incidence of breathing movements in all three groups after maternal glucose administration: Group A $(p=0.025)$, group $B(p<0.05)$, group $C(p=$ 0.05). Comparing group $A$ with $B$, there was no significant difference in the incidence of breathing movements during the control period, but there was a significant difference in favor of group A after maternal glucose administration $(p<0.02)$. Comparing group $A$ with $\mathrm{C}$ there was a significant difference in breathing activity in favor of group A in both recording periods $(p<0.01)$. Comparing group $B$ with $C$, no significant difference was found in any recording period. No breathing movements were noted in 4 out of 8 fetuses in group $C$ and in 2 out of 12 fetuses in group B prior to maternal glucose administration.

\section{Discussion}

The policy in our department is attempt to induce labor at the end of 42 weeks of gestation.
We believe that as a result only stage I of postmaturity was found in eight fetuses from prolonged pregnancies. Fetal body and breathing movements have been suggested as indicators of fetal wellbeing. Reduction or absence of these activities is regarded as an alarming sign of pregnancy complications $[5,6]$.

In our study it was found that breathing activity is significantly reduced in postmature fetuses when compared to mature fetuses. In fifty percent of postmature fetuses there was no breathing activity in the control period prior to maternal glucose administration. The number of the fetuses is small but it is important to note that all these fetuses were only at stage I of postmaturity. and it could be suggested that in stage II-III of postmaturity the situation may be worse. It is also of interest to note that even fetuses at 42 weeks gestation who had no signs of postmaturity were unable to increase their breathing activity after glucose to the same level as the mature one. Maternal glucose administration is known to increase breathing activity in normal fetuses. Recently it has been shown that even growth retarded fetuses may increase their breathing activity to some extent after such stimulation [4]. A modification of fetal reactivity from a non reactive NST to a reactive one was also noted [3]. The fact that increased breathing activity was noted after glucose in all three groups of our study, as well

Tab. I. Incidence of fetal breathing movements (duration in seconds) before and after maternal glucose administration.

\begin{tabular}{|c|c|c|c|c|c|c|c|c|c|c|c|c|}
\hline Case & 1 & 2 & 3 & 4 & 5 & 6 & 7 & 8 & 9 & 10 & 11 & 12 \\
\hline $\bar{G}$ roun A & 198 & 412 & 561 & 77 & 257 & 791 & & & & & & \\
\hline+ & 874 & 885 & 1005 & 562 & 430 & 790 & & & & & & \\
\hline $\bar{G}$ roun B & 41 & 167 & 697 & 86 & 0 & 11 & 0 & 209 & 476 & 640 & 104 & 31 \\
\hline+ & 734 & 233 & 640 & 0 & 267 & 787 & 55 & 239 & 750 & 349 & 479 & 781 \\
\hline$\overline{\text { Group C }}$ & 0 & 0 & 52 & 223 & 203 & 0 & 13 & 0 & & & & \\
\hline+ & 103 & 101 & 185 & 11 & 449 & 130 & 785 & 430 & & & & \\
\hline
\end{tabular}


as the normal incidence of body movements recorded could be regarded as a sign of compromise in the fetuses of prolonged pregnancies.
We suggest that reduction in breathing movements is an early sign of fetal distress in prolonged pregnancies.

\section{Summary}

Fetal body movements and breathing movements were recorded with a real time ultrasound scanner in 26 fetuses. There were two recording periods of $25 \mathrm{~min}$ each, before and half and hour after maternal IV administration of $50 \mathrm{gr}$ glucose. Six fetuses were at 280 days of gestation (group A), twelve fetuses were at 294 days of gestation (group B), eight fetuses at 294 days gestation were classified as stage I postmature (group C).

The incidence of fetal body movements was not sig- nificantly different in the three groups. Maternal glucose administration had no significant influence on fetal body movements in any group. On the other hand fetal breathing activity was significantly increased in all three groups after maternal glucose administration. Breathing activity was significantly greater in group $\mathrm{A}$ when compared to group $C$ in both recording periods, and when compared to group $B$ in the period which followed maternal glucose administration. It is concluded that fetal breathing activity is reduced in prolonged pregnancies.

Keywords: Fetal body movements, fetal breathing movements, glucose, postmature, prolonged pregnancy.

\section{Zusammenfassung}

Intrauterine fetale Aktivität bei Schwangerschaften am Termin und übertragenen Schwangerschaften

Bei 26 Feten wurden die Kindsbewegungen und Thoraxexkursionen mit einem Real-time-Ultraschallgerät beobachtet. Jeweils eine halbe Stunde vor bzw. nach der intravenösen Gabe von $50 \mathrm{~g}$ Glucose an die Mutter betrug der Beobachtungszeitraum je 25 Minuten. Gruppe A umfaßte 6 Fälle mit einer Schwangerschaftsdauer von 280 Tagen und Gruppe B 12 Fälle mit einer Dauer von 294 Tagen. In Gruppe C sind 8 Fälle mit einer Schwangerschaftsdauer von 294 Tagen enthalten, die als Übertragung Stadium I klassifiziert wurden.
Bezüglich der fetalen Bewegungen gab es zwischen den 3 Gruppen keine signifikanten Unterschiede. Die Gabe von Glucose hatte keinen Einfluß auf das Ausmaß der Kindsbewegungen. Dagegen stieg die Anzahl der Atemexkursionen in allen 3 Gruppen nach Glucosegabe signifikant an. In beiden Beobachtungsphasen waren die Atemexkursionen in Gruppe A häufiger als in Gruppe C. Nach Glucosegabe traten in Gruppe A häufiger Thoraxbewegungen auf als in Gruppe B. Wir schließen daraus, daß bei übertragenen Schwangerschaften die fetale Atemaktivität reduziert ist.

Schlüsselwörter: fetale Atemexkursionen, Glucose, Kindsbewegungen, Postmaturität, übertragene Schwangerschaften.

\section{Résumé}

Activité fọtale intra-utérine, à terme et au cours des grossesses prolongées

On a enregistré chez 26 fœtus à l'aide d'un échographie en temps réel, les mouvements corporels et les mouvements respiratoires. Deux périodes d'enregistrement de 25 minutes chacunes ont été effectuées, avant et une demi-heure après l'injection intra-veineuse de 50 grammes de glucose à la mère. Six fœtus étaient à 280 jours de grossesse (groupe A), 12 fœtus à 294 jours (groupe B) et 8 fœtus à 294 jours classés dans le stade I de postmaturité (groupe C).

Il n'y a pas de différence significative dans l'incidence des mouvements corporels du fœtus entre les 3 groupes.
L'injection de glucose à la mère n'a pas d'influence significative sur les mouvements corporels du fetus dans quelques groupe que ce soit.

Par ailleurs, l'activité respiratoire du fotus est significativement augmentée dans les 3 groupes après l'injection de glucose à la mère. L'activité respiratoire est significativement plus importante dans le groupe A que dans le groupe $\mathrm{C}$ au cours des 2 périodes d'enregistrement et plus importante que dans le groupe $\mathrm{B}$ au cours de la deuxième période d'enregistrement.

Les auteurs concluent que les mouvements respiratoires du fetus sont dimminués au cours des grossesses prolongées.

Mots-clés: Glucose, grossesses prolongées, mouvements corporels du fœtus, mouvements, respiratoires du fœtus, post-maturité. 


\section{Bibliography}

[1] Clifford, S. H.: Postmaturity - with placental dysfunction. Clinical syndrome and pathologic findings. J. Pediatr. 44 (1954) 1

[2] Field, T. M., C. Dabiri, N. Hallock, H. H. ShUMAN: Developmental effects of prolonged pregnancy and the postmaturity syndrome. J. Pediatr. 90 (1977) 836

[3] Graca, L. M., M. Meirinho, J. Formosinho SANCHES, J. SaRaIVA: Modification of the fetal reactivity by an introvenous glucose load to the mother. J. Perinat. Med. 9 (1981) 286

[4] Luther, F. R., J. H. Gray, K. Scott, A. Allen, D. STINSON: The effect of maternal glucose infusion on breathing movements in human fetuses with intrauterine growth retardation. Am. J. Obstet. Gynecol. 142 (1982) 600

[5] MARSAL, K.: Fetal breathing movements, characteristics and clinical significance. Obstet. Gynecol. 52 (1978) 394 is

[6] Platt, D. L., G. S. Eglinton, L. Sipos, P. M. Broussard, R. H. PAUL: Further experience with the fetal biophysical profile. Obstet. Gynecol. 61 (1983) 480

[7] Rayburn, W. F., M. E. Motley, L. E. Stempel, R. M. GendreaU: Antepartum prediction of the postmature infant. Obstet. Gynecol. 60 (1982) 148

[8] Thornton, Y.S., S. Y. YeH, R. H. Petrie: Antepartum fetal heart rate testing and the postterm gestation. J. Perinat. Med. 10 (1982) 196

Received May 25, 1984. Accepted August 31, 1984.

Etan Z. Zimmer, M. D.

Dept. of Obstetrics/Gynecology

Rambam Medical Center

Technion. Faculty of Medicine

Haifa, Israel 